\title{
Ball lightning: a Renaissance account from Zafra (Spain)
}

\author{
José M. Vaquero ${ }^{1,2}$ \\ ${ }^{1}$ Departamento de Física, Universidad de Extremadura, 06800 Mérida, Spain \\ ${ }^{2}$ Instituto Universitario de Investigación del Agua, Cambio Climático y Sostenibilidad (IACYS), \\ Universidad de Extremadura, 06006 Badajoz, Spain
}

Correspondence to: José M. Vaquero (jvaquero@unex.es)

Received: 30 March 2017 - Revised: 8 May 2017 - Accepted: 16 May 2017 - Published: 12 June 2017

\begin{abstract}
An analysis is given of the account of a "globe of fire" observed in Zafra (Spain) in the middle of the 16th century. During a strong storm, Conde Don Pedro observed what he described as a "globe of fire" that was directed against the city and abruptly changed course. He attributed the change in course to a miracle. He described neither any damage nor sound.
\end{abstract}

\section{Introduction}

The Iberian Peninsula's participation in the beginnings of the so-called "scientific revolution" is an issue that has received considerable attention from historians of modern science in recent years. For centuries, the contributions of Spanish and Portuguese scientists to science and technology had been excluded from studies of the "scientific revolution". According to Cañizares-Esguerra (2004), the roots of this exclusion lay in the Protestant Reformation and the Enlightenment. In any case, there have now been various academic studies that delve into the crucial participation of Iberian scientists in the 16th century. The pioneering book of López Piñero (1979) is particularly worthy of mention because it gave a major impulse to this type of study. Two other notable, and more recent, works are the collective volume edited by Navarro Brotóns and Eamon (2007) and the book by Portuondo (2009). With respect to singular meteorological phenomena, an early graphical representation stands out of a tornado and other meteorological events in a collection of 16th century tapestries of Belgian origin, a territory under the Spanish crown at the time (Hoinka and de Castro, 2005).

In this context of studies on science in the Iberian Renaissance, this brief note will describe the interesting episode represented by a reference to a singular meteorological phenomenon observed by the Conde de Feria in the second quarter of the 16th century in the town of Zafra $\left(38^{\circ} 25.5^{\prime} \mathrm{N}\right.$, $6^{\circ} 25^{\prime} \mathrm{W} ; 508 \mathrm{~m}$ ) in the region of Extremadura (Spain). In Spanish historiography, the phenomenon has been presented as a miracle. The present note proposes that it be classified as a "ball lightning" sighting.

"Ball lightning" is an exceptional meteorological phenomenon generally related to intense storms. Its description corresponds to a persistent, bright, floating object, unlike the commoner, brief discharge of a lightning bolt. In any case, the phenomenological descriptions are very diverse. There have been modern observations of this type of phenomenon both at rest and in motion (Barry, 1974; Stenhoff, 1999). Curiously, the physics of ball lightning is far more complicated than it might seem, and there is still no single theory that can successfully explain the variety of characteristics that ball lightning shows. One can consult recent articles by Wu (2016), Stephan et al. (2016), and Bychkova et al. (2016).

\section{Historical source}

The oldest text in which the "miracle" appears of Don Pedro, the Conde de Feria, is the "Chronica de la Santa Provincia de San Miguel" of Fray Joseph de Santa Cruz, published in 1671. In this book, one can read the following description:

Del otro caso dio testimonio el Conde Don Pedro afirmando que en una tempestad furiosa de truenos y relámpagos, de que cayeron algunas centellas con daño de muchos edificios, y personas, se asomó a una ventana de palacio, y vio que un espantoso globo de fuego se iba revolviendo hacia el convento de Santa Clara, con que presumió que todo se ardería, o destruiría: y que a ese tiempo de 


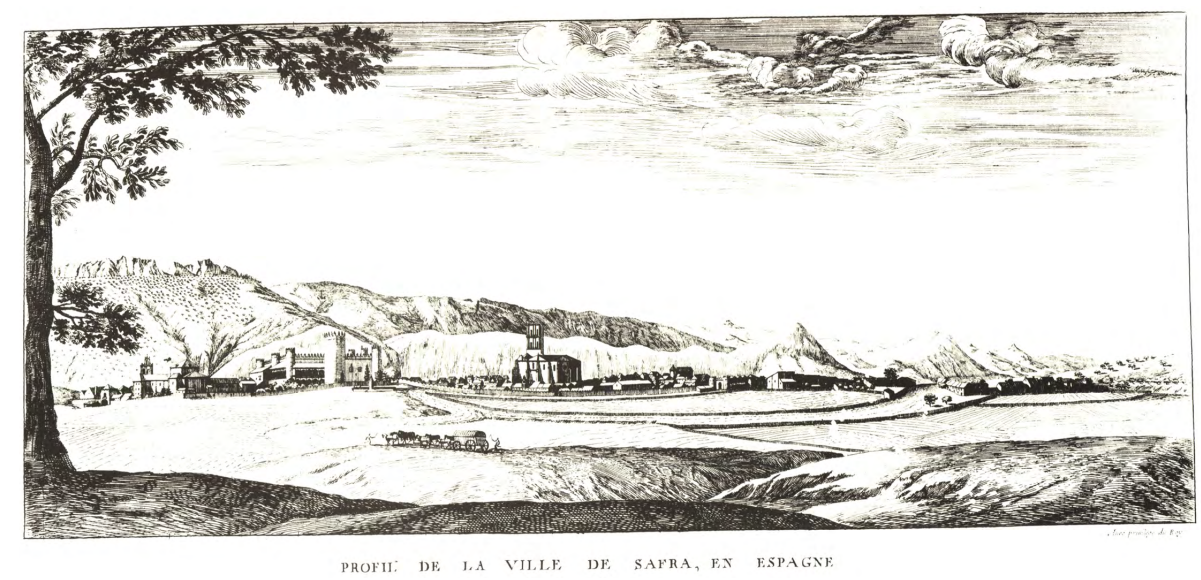

Figure 1. The town of Zafra in about 1660. The two important buildings on the left-hand side of the image are the Santa Clara Convent (first on the left) and the Alcázar de Zafra (second on the left). The important building in the central part of the image is the Collegiata church. The "Peñas del Castellar" mentioned by Fr. Joseph de Santa Cruz are the highest hills seen on the left of the image (courtesy of the Zafra Municipal Historical Archive).

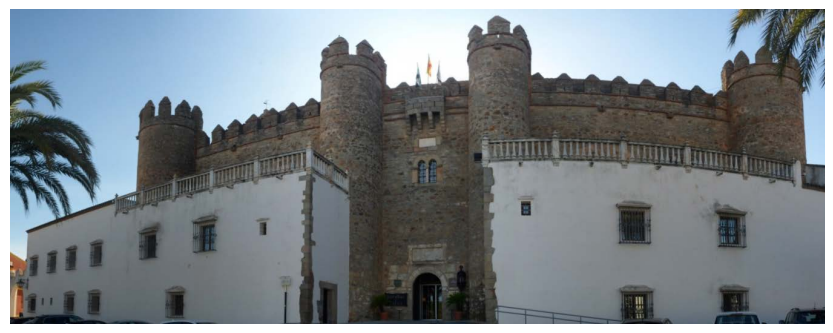

Figure 2. A modern panoramic view of the main facade of the Alcázar de Zafra nowadays. From this palace, Count Don Pedro observed the ball lightning.

la parte del Convento apareció una mano en el aire, y dando un golpe en el globo ardiente le rechazó, y arrojó a las peñas del Castellar (que es un cerro cerca de la villa a la parte de Poniente), adonde se desvaneció todo aquel incendio. Con tan evidentes indicios se probó la protección de nuestra Señora del Valle, y la Religiosidad, y santidad de esta casa. [From the other case, Count Don Pedro testified, stating that, in a furious storm of thunder and lightning, from which some sparks fell with damage of many buildings and persons, he looked out of a palace window, and saw that a frightful globe of fire was revolving and going towards the convent of Santa Clara, with which he assumed that everything would burn, or destroy [be destroyed]: and that at that time from the part of the convent there appeared a hand in the air, and giving a blow to the burning globe rejected it, and threw [it] to the rocks of the Castellar (which is a hill near the town to the part of the west), where all that fire faded. With such clear evidence was proven the protection of

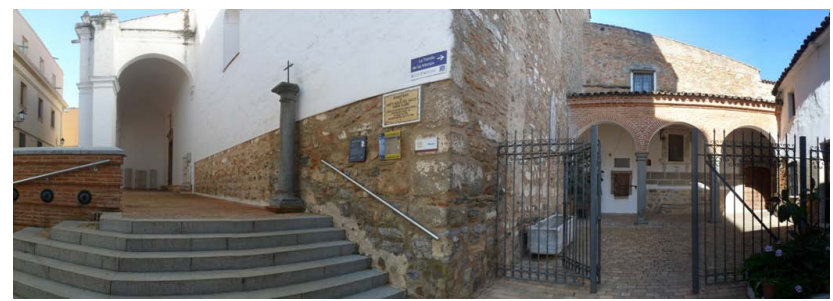

Figure 3. A modern panoramic view of the convent of Santa Clara.

Our Lady of the Valley, and of the religiosity, and holiness of this house.] (Santa Cruz, 1671, p. 526.)

This text fixed the story that would have spread by word of mouth among the faithful related to the convent of Santa Clara in Zafra. Count Don Pedro, one of the convent's benefactors, had watched from a window of the Alcázar (the Renaissance palace where he lived) how this convent had been saved from destruction by a "globe of fire" when it, which had been on a path towards the convent, abruptly deviated from this path at the last moment. The "globe of fire" then went to a range of small hills called the Castellar located to the west of Zafra, and there disappeared. Figure 1 is a fairly reliable historical picture in which one can clearly see the buildings mentioned in the narrative (which were, after the Collegiata church, the town's most outstanding constructions), as well as the rocky formation of the Castellar. Figures 2 and 3 show modern panoramic views of the main facade of the Alcázar and the convent of Santa Clara, respectively. After this first text of the miracle, other authors reproduced, copied, or modified Fr. Joseph de Santa Cruz's account. An example is a manuscript of Father Matamoros entitled Historia de Zafra, dated 1828 , which has recently been edited and published (Matamoros, 2008). 


\section{Discussion}

Regrettably, the earliest known telling of the "miracle" witnessed by Count Don Pedro is a secondary source published more than a century after the occurrence of the phenomenon. For this reason, we must eliminate the more supernatural elements and focus attention on the more essential and objective aspects of the narrative as briefly mentioned above.

The date of Count Don Pedro's observation of this "globular lightning" is unknown. Although he maintained strong ties with the town of Zafra throughout his life, he resided outside it for much time, making numerous journeys related to his position of a noble of the court. His full name was Pedro Fernández de Córdoba y Figueroa. He was the fourth Count of Feria and Lord of the states of Zafra and Villalba, and the House of Figueroa. He was born in 1519, possibly in Montilla, and died in Priego on 27 August 1552 at age 33 (Valencia Rodríguez, 2010). One can not specify more precisely the date of the phenomenon's observation. One can indicate, however, that it probably took place in the period 1546-1550 when Count Don Pedro spent a long time residing in Zafra. The scientific literature includes some references to reports of this type of atmospheric phenomenon in historical sources (Coleman, 2006; Durand and Wilson, 2006; Farrona and Vaquero, 2012). None, however, correspond to examples earlier than that reported by Count Don Pedro. In any case, there is a long history of reports of "fireballs" that could be of very different natural origin (Hipkins, 2009).

The characteristics of the phenomenon reported by Count Don Pedro are common to other historical and modern observations of ball lightning. The occurrence of the phenomenon coincides with a "furious storm of thunder and lightning". In addition, the ball of fire described by Count Don Pedro is in motion and makes a sudden change in course at a certain point where the witness sees the "hand of God". One should also note that the narrative does not indicate any sound associated with the observation of the phenomenon, and nor is any type of damage reported.

\section{Conclusion}

This brief note has salvaged an unusual record of ball lightning dating, unfortunately without precision, to the period 1546-1550. Although one only has this secondary historical source, the objective data of the narrative correspond to the observation of ball lightning associated with a major storm. This secondary text also describes the ball lightning being in movement and making a sudden change of course. The informant does not, however, indicate anything about the colour or sound, and nor does he report any type of damage.

Data availability. No data sets were used in this article.
Competing interests. The authors declare that they have no conflict of interest.

Acknowledgements. The author thanks José María Moreno, Head of the Municipal Historical Archive of Zafra, for his helpful comments and suggestions. This research was supported by the Economy and Infrastructure Counseling of the Junta of Extremadura through project IB16127 and grant GR15137 (co-financed by the European Regional Development Fund) and by Ministerio de Economía y Competitividad of the Spanish Government (AYA2014-57556-P).

Edited by: K. Schlegel

Reviewed by: A. Wittmann and one anonymous referee

\section{References}

Barry, J. D.: A Comprehensive Bibliography of Ball Lightning Reports, Air Force Avionics Laboratories, A.F.S.C., Wright Patterson AFB, Ohio, OH, 1974.

Bychkova, V. L., Nikitinb, A. I., Ivanenkoa, I. P., Nikitinab, T. F., Velichkob, A. M., and Nosikovc, I. A.: Ball lightning passage through a glass without breaking it, J. Atmos. Sol.-Terr. Phy., 150-151, 69-76, 2016.

Cañizares-Esguerra, J.: Iberian Science in the Renaissance: Ignored How Much Longer?, Perspect. Sci., 12, 86-124, 2004.

Coleman, P. F.: Ball lightning fireballs seen in the 1783 Laki vog, Weather, 61, 293-294, 2006.

Durand, M. and Wilson, J. G.: Ball lightning and fireballs during volcanic air pollution, Weather, 61, 40-43, 2006.

Farrona, A. M. M. and Vaquero, J. M.: An early scientific report of ball lightning from Brazil, Weather, 67, 96-97, 2012.

Hipkins, C. R.: Fireballs: A History of Meteors and other Atmospheric Phenomena, Xlibris, Bloomington, Indiana, USA, 2009.

Hoinka, K. and de Castro, M.: A Renaissance Depiction of a Tornado, B. Amer. Meteorol. Soc., 86, 543-552, 2005.

López Piñero, J. M.: Ciencia y técnica en la sociedad española de los siglos XVI y XVII, Editorial Labor, Barcelona, 1979.

Matamoros, A.: Historia de Zafra por el reverendo padre fray Antonio Matomoros del Orden de Santo Domingo 1828 (edition, introduction and notes by José María Lama Hernández and Juan Carlos Rubio Masa), Centro de Estudios del Estado de Feria, Zafra, 2008.

Navarro Brotóns, V. and Eamon, W. (Eds.): Más allá de la Leyenda Negra: España y la Revolución Científica (Beyond the Black Legend: Spain and the Scientific Revolution), Instituto de Historia de la Ciencia y Documentación López Piñero, Valencia, 2007.

Portuondo, M. M.: Secret Science: Spanish Cosmography and the New World, The Chicago University Press, Chicago, 2009.

Santa Cruz, J.: Chronica de la Santa Provincia de S. Miguel de la Orden de N. Serafico Padre S. Francisco, Viuda de Melchor Alegre, Madrid, 1671.

Stenhoff, M.: Ball Lightning - An Unsolved Problem in Atmospheric Physics. Kluwer Stott, Academic Publisher, New York, NY, 1999. 
Stephan, K. D., Krajcik, R., and Martin, R. J.: Fluorescence caused by ionizing radiation from ball lightning: Observation and quantitative analysis, J. Atmos. Sol.-Terr. Phy., 148, 32-38, 2016.

Valencia Rodríguez, J. M.: El poder señorial en la edad moderna: la casa de Feria (siglos XVI y XVII), Diputación Provincial de Badajoz, Badajoz, 2010.
Wu, H.-C.: Relativistic-microwave theory of ball lightning, Nat. Scient. Rep., 6, 28263, 2016. 